\title{
Changes in ABA, IAA, GA3, and ZR Levels during Seed Dormancy Release in Idesia polycarpa Maxim from Jiyuan
}

\author{
Wang Yanmei, Wang Lijun, Yao Bing, Liu Zhen*, Li Fei \\ College of Forestry, Henan Agricultural University, Zhengzhou, Henan, 450002, P. R. China
}

Received: 14 July 2017

Accepted: 27 September 2017

\begin{abstract}
We analyzed changes in abscisic acid (ABA), indole-3-acetic acid (IAA), Gibberellin $\mathrm{A}_{3}\left(\mathrm{GA}_{3}\right)$, and trans-Zeatin-riboside (ZR) content in seeds of Idesia polycarpa Maxim. Plant hormones have been widely studied for their roles in the regulation of various aspects related to plant development and, in particular, into their action during seed dormancy release. The obtained evidence suggest that the functions of these hormones are not restricted to a particular development stage, and that more than one hormone is involved in controlling various aspects of plant development. Our results will contribute to understanding the role of these hormones during seed dormancy release in Idesia polycarpa Maxim. The contents and balance of endogenous hormones in I. Polycarpa seeds changed during the chilling treatment. The contents of IAA, $\mathrm{GA}_{3}$, and $\mathrm{ZR}$ and the dynamic ratios of hormones were higher in the chilling treatment than in the control. The ABA content was lower than in the control. The chilling treatment released seed dormancy and significantly improved the seed germination rate. The germination rate was significantly negatively correlated with the contents of IAA and ABA, and positively correlated with the following ratios: $\left.\mathrm{GA}_{3} / \mathrm{ABA}, \mathrm{GA}_{3}+\mathrm{ZR}\right) / \mathrm{ABA},\left(\mathrm{IAA}, \mathrm{GA}_{3}\right.$ and $\left.\left.\mathrm{ZR}\right) / \mathrm{ABA}, \mathrm{GA}_{3} / \mathrm{ABA}+\mathrm{IAA}\right)$, and $\left(\mathrm{GA}_{3}+\mathrm{ZR}\right) /(\mathrm{ABA}$ + IAA).
\end{abstract}

Keywords: abscisic acid (ABA), Indole-3-acetic acid (IAA), Gibberellin $\mathrm{A}_{3}\left(\mathrm{GA}_{3}\right)$, trans-Zeatin-riboside (ZR), Idesia polycarpa Maxim

\section{Introduction}

Idesia polycarpa Maxim. (Flacourtiaceae) is an adeciduous tree with a straight, strong trunk, adaptabile to a wide range of environmental conditions, fast growth, strong tolerance to cold and drought, and wide distribution. It is often used as a greening and ornamental tree species,

*e-mail: liuzh20@163.com and is also used for wood oil production. In fact, it is known as the 'beautiful tree oil depot'. The germination rate of $I$. polycarpa seeds is very low. Several studies have reported methods to improve the germination rate, for example by removing the waxy outer layer; immersing in alkaline and straw ash water [1-3]; dewaxing, low-temperature, and wet sand treatment [4]; and a low-temperature and wet sand treatment [5]. However, none of these methods was completely successful. Wang found that I. Polycarpa seeds have a dormant character [6]. Many factors affect seed dormancy [7]. 
Plant hormones play a key role in most physiological processes, and a central role in the integration of diverse environmental cues with the plant genetic program and in shaping morphological structures. They are directly involved in seed dormancy release [8-9].

Abscisic acid (ABA) modulates numerous aspects of plant life, including seed dormancy, embryo maturation, and plant responses to different kinds of abiotic stresses such as drought, high temperature, chilling, and salinity. The seed dormancy release process of seeds is controlled by several hormones such as auxins, brassinosteroids, and ABA. In addition, indole-3-acetic acid (IAA), Gibberellin $\mathrm{A}_{3}\left(\mathrm{GA}_{3}\right)$, and trans-Zeatin-riboside (ZR) play a major role in the regulation of seed dormancy release. However, there is a lack of works on endogenous changes of Idesia polycarpa Maxim, such as ABA, IAA, GA, and ZR obtained from seeds. The aim of this work was to investigate the changes in endogenous hormone contents in seeds of Jiyuan provenance of I. polycarpa during the release of dormancy under low temperature, and to analyze the relationship between endogenous hormone content and dormancy release. These results provide important information about the seed dormancy release mechanism of I. Polycarpa and provide the theoretical basis and technical support for breeding this important species.

\section{Materials and Methods}

\section{Experimental Materials}

Mature, well-filled seeds of I. polycarpa were collected from Jiyuan Manghe Forest, Henan Province, which is on the northern margin of the distribution I. polycarpa in China.

\section{Experimental Methods}

Moist I. polycarpa seeds were kept in an artificial climate box (LRH-250-GS I, Guangzhou, China) at $5^{\circ} \mathrm{C}$ for $60 \mathrm{~d}$ and sampled at $0 \mathrm{~d}, 20 \mathrm{~d}, 40 \mathrm{~d}$ and $60 \mathrm{~d}$. For the control (CK), seeds were kept under natural conditions and sampled at the same times. To test their germination potential, the seeds were placed in Petri dishes (100

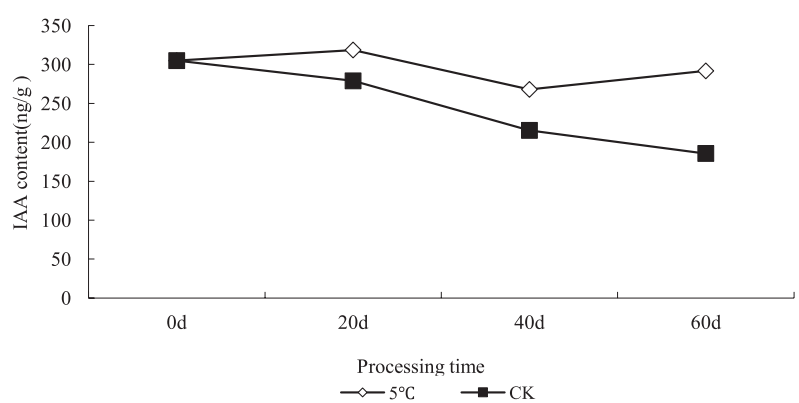

Fig. 1. Change in IAA content in Idesia polycarpa seeds from Jiyuan during a chilling treatment at $5^{\circ} \mathrm{C}$. seeds per dish) and kept under a variable temperature regime (night temperature $15^{\circ} \mathrm{C}$, daytime temperature $25^{\circ} \mathrm{C}-12 \mathrm{~h}$ each). Each treatment was replicated three times. The number of germinated seeds was counted every 5 days. High performance liquid chromatography (HPLC) [10] was used to quantify the endogenous hormone contents in all of the seed samples.

\section{Results and Discussion}

\section{Effect of $5^{\circ} \mathrm{C}$ Treatment on Endogenous Hormone Contents of $I$. polycarpa Seeds}

\section{IAA Content}

As shown in Fig. 1, during the $5^{\circ} \mathrm{C}$ treatment, the IAA content of seeds first increased, then decreased, then increased. The highest IAA content was at $20 \mathrm{~d}$ (318.58 ng/g) and the lowest was at $40 \mathrm{~d}(267.94 \mathrm{ng} / \mathrm{g})$. The difference in IAA content among different time points during the $5^{\circ} \mathrm{C}$ treatment was extremely significant $(p<0.01)$. In the $\mathrm{CK}$, IAA content decreased during the 60 -day incubation period. The highest IAA content was at $0 \mathrm{~d}(304.92 \mathrm{ng} / \mathrm{g})$ and the lowest was at $60 \mathrm{~d}(185.68 \mathrm{ng} / \mathrm{g})$. The difference in IAA content among different time points was extremely significant $(p<0.01)$. The IAA content was higher in the seeds in the $5^{\circ} \mathrm{C}$ treatment than in those in CK. There was a high IAA content in seeds in the $5^{\circ} \mathrm{C}$ treatment and in the $\mathrm{CK}$.

\section{GA $A_{3}$ Content}

During the $5^{\circ} \mathrm{C}$ treatment, the $\mathrm{GA}_{3}$ content decreased, then increased, and then decreased (Fig. 2). The lowest $\mathrm{GA}_{3}$ content was at $20 \mathrm{~d}(146.75 \mathrm{ng} / \mathrm{g})$ and the highest was at $40 \mathrm{~d}(188.49 \mathrm{ng} / \mathrm{g})$. The $\mathrm{GA}_{3}$ content did not differ significantly between $0 \mathrm{~d}$ and $60 \mathrm{~d}(\mathrm{p}>0.05)$, but differed significantly among the other time points $(\mathrm{p}<0.01)$. In the $\mathrm{CK}$, the $\mathrm{GA}_{3}$ content decreased over time. The highest $\mathrm{GA}_{3}$ content was at $0 \mathrm{~d}(168.62 \mathrm{ng} / \mathrm{g})$ and the lowest was at $60 \mathrm{~d}(110.70 \mathrm{ng} / \mathrm{g})$. The $\mathrm{GA}_{3}$ content differed significantly between 0 and $20 \mathrm{~d}(\mathrm{p}<0.01)$, but not among the other time points $(\mathrm{p}>0.05)$.

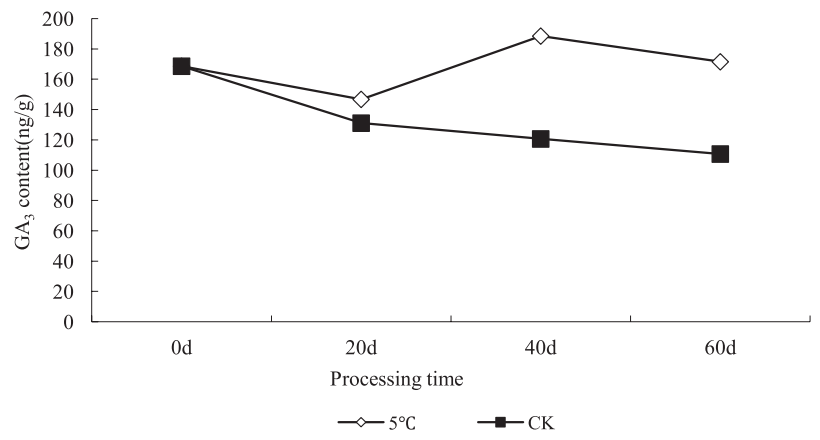

Fig. 2. Change in $\mathrm{GA}_{3}$ content in Idesia polycarpa seeds from Jiyuan during a chilling treatment at $5^{\circ} \mathrm{C}$. 


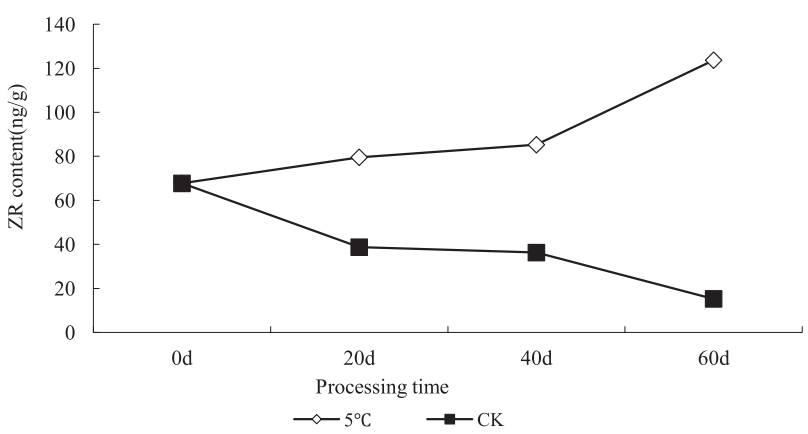

Fig. 3. Change in ZR content in Idesia polycarpa seeds from Jiyuan during a chilling treatment at $5^{\circ} \mathrm{C}$.

\section{ZR Content}

In the $5^{\circ} \mathrm{C}$ treatment, the $\mathrm{ZR}$ content increased over time (Fig. 3). The lowest ZR content was at $0 \mathrm{~d}$ $(67.73 \mathrm{ng} / \mathrm{g})$ and the highest was at $60 \mathrm{~d}(123.70 \mathrm{ng} / \mathrm{g})$. The ZR content did not differ significantly between $20 \mathrm{~d}$ and $40 \mathrm{~d}$, but differed significantly among the other time points $(\mathrm{p}<0.05)$ - especially between $40 \mathrm{~d}$ and $60 \mathrm{~d}(\mathrm{p}<0.01)$. The ZR content decreased over time in CK. The highest content of ZR was at $0 \mathrm{~d}(67.73 \mathrm{ng} / \mathrm{g})$ and the lowest was at $60 \mathrm{~d}(15.25 \mathrm{ng} / \mathrm{g})$. The ZR content did not differ significantly between $20 \mathrm{~d}$ and $40 \mathrm{~d}$ ( $\mathrm{p}>0.05)$, but differed significantly among the other time points $(\mathrm{p}<0.01)$.

\section{ABA Content}

During the $5^{\circ} \mathrm{C}$ treatment, the ABA content decreased and then increased (Fig. 4). The highest ABA content was at $0 \mathrm{~d}(668.40 \mathrm{ng} / \mathrm{g})$ and the lowest was at $40 \mathrm{~d}$ $(466.78 \mathrm{ng} / \mathrm{g})$. The ABA content did not differ significantly between $20 \mathrm{~d}$ and $60 \mathrm{~d}(p>0.05)$, but differed significantly among the other time points $(p<0.01)$. In the CK, the ABA content decreased slightly over time. The highest ABA content was at $0 \mathrm{~d}(668.40 \mathrm{ng} / \mathrm{g})$ and the lowest was at $60 \mathrm{~d}(617.37 \mathrm{ng} / \mathrm{g})$. The ABA content differed significantly between $20 \mathrm{~d}$ and $60 \mathrm{~d}(p<0.01)$, but not among other time points $(p>0.05)$.

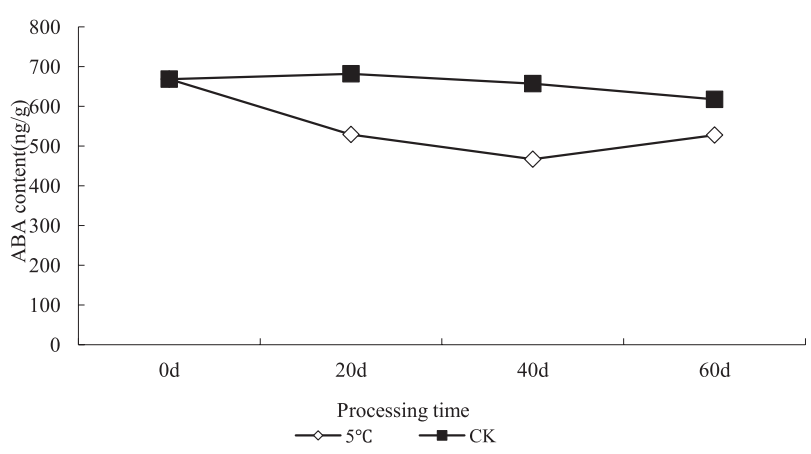

Fig. 4. Change in ABA content in Idesia polycarpa seeds from Jiyuan during a chilling treatment at $5^{\circ} \mathrm{C}$.

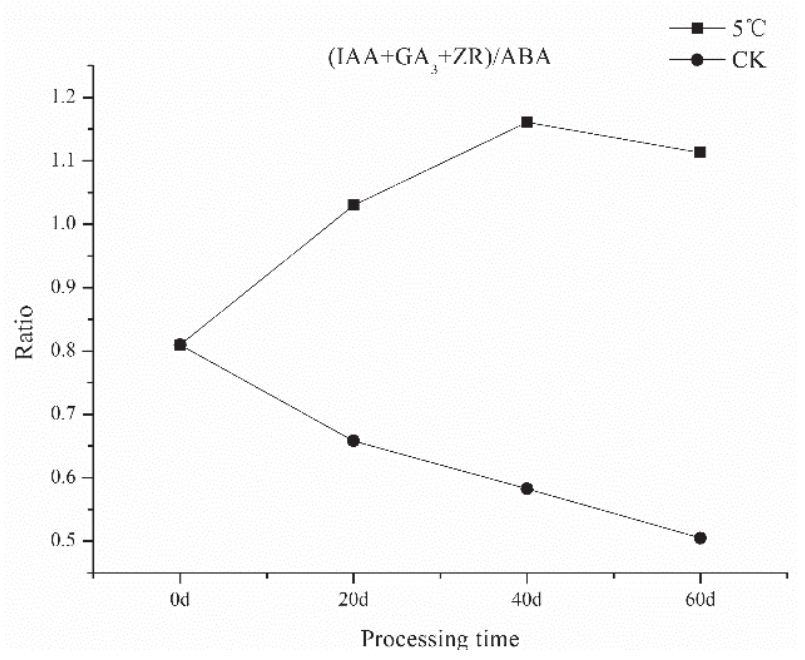

Fig. 5. Change of $\left(\mathrm{IAA}+\mathrm{GA}_{3}+\mathrm{ZR}\right) / \mathrm{ABA}$ in Idesia polycarpa seeds from Jiyuan during a chilling treatment at $5^{\circ} \mathrm{C}$.

\section{Dynamic Balance of Endogenous Hormones}

During the $5^{\circ} \mathrm{C}$ treatment (Fig. 5), the following hormone ratios increased and then decreased: $\left(\mathrm{IAA}+\mathrm{GA}_{3}+\mathrm{ZR}\right) / \mathrm{ABA} ; \quad \mathrm{GA}_{3} / \mathrm{ABA} ; \quad \mathrm{GA}_{3} /(\mathrm{ABA}+\mathrm{IAA})$; $\left(\mathrm{GA}_{3}+\mathrm{ZR}\right) /(\mathrm{ABA}+\mathrm{IAA})$. The following hormone ratios increased: (IAA+GA $) / A B A ; \quad(\mathrm{IAA}+\mathrm{ZR}) / \mathrm{ABA}$; $\left(\mathrm{GA}_{3}+\mathrm{ZR}\right) / \mathrm{ABA}$; IAA/ABA; ZR/ABA; ZR/(ABA+IAA).

In the $C K$, the following ratios showed a decreasing trend: $\quad\left(\mathrm{IAA}+\mathrm{GA}_{3}+\mathrm{ZR}\right) / \mathrm{ABA} ; \quad\left(\mathrm{IAA}+\mathrm{GA}_{3}\right) / \mathrm{ABA}$; $(\mathrm{IAA}+\mathrm{ZR}) / \mathrm{ABA}$; IAA/ABA. The following ratios increased, decreased, and then increased: $\left(\mathrm{GA}_{3}+\mathrm{ZR}\right) /$ ABA; GA $/ \mathrm{ABA} ; \mathrm{ZR} / \mathrm{ABA} ; \mathrm{GA}_{3} /(\mathrm{ABA}+\mathrm{IAA}) ; \mathrm{ZR} /$ $(\mathrm{ABA}+\mathrm{IAA}) ;\left(\mathrm{GA}_{3}+\mathrm{ZR}\right) /(\mathrm{ABA}+\mathrm{IAA})$.

\section{Effect of $5^{\circ} \mathrm{C}$ Treatment on Germination Rate of I. polycarpa Seeds at $15 / 25^{\circ} \mathrm{C}$}

From Table 1, The seeds removed from the $5^{\circ} \mathrm{C}$ treatment at $20 \mathrm{~d}, 40 \mathrm{~d}$, and $60 \mathrm{~d}$ showed germination rates of $80.33 \%, 90.67 \%$, and $98 \%$, respectively, when

Table 1. Variance analysis of germination rate of Idesia polycarpa seeds at $15 / 25^{\circ} \mathrm{C}$ after a $5^{\circ} \mathrm{C}$ chilling treatment.

\begin{tabular}{|c|c|c|}
\hline $\begin{array}{c}\text { Low temperature } \\
\text { treatment time (d) }\end{array}$ & $\begin{array}{c}\text { Germination rate } \\
\text { with } 5^{\circ} \mathrm{C} \text { treatment } \\
(\%)\end{array}$ & $\begin{array}{c}\text { CK germination } \\
\text { rate without } 5^{\circ} \mathrm{C} \\
\text { treatment }(\%)\end{array}$ \\
\hline 0 & $36.7 \pm 1.6 \mathrm{dD}$ & $36.7 \pm 1.6 \mathrm{dD}$ \\
\hline 20 & $80.3 \pm 1.6 \mathrm{cC}$ & $34.7 \pm 0.9 \mathrm{dD}$ \\
\hline 40 & $90.7 \pm 2.9 \mathrm{bB}$ & $33.3 \pm 2.9 \mathrm{dD}$ \\
\hline 60 & $98.0 \pm 0.7 \mathrm{aA}$ & $33.7 \pm 1.6 \mathrm{dD}$ \\
\hline
\end{tabular}

Note: different lowercase letters in the same column indicate significant difference $(p<0.05)$, and different capital letters indicate extremely significant difference $(p<0.01)$ 
Table 2. Correlation analysis between endogenous hormone content and seed germination rate at $15 / 25^{\circ} \mathrm{C}$ after a $5^{\circ} \mathrm{C}$ chilling treatment.

\begin{tabular}{|c|c|c|c|c|c|}
\hline & IAA & $\mathrm{ABA}$ & $\mathrm{GA}_{3}$ & $\mathrm{ZR}$ & $\begin{array}{c}\text { Germination } \\
\text { rate }\end{array}$ \\
\hline $\mathrm{IAA}$ & 1 & & & & \\
\hline $\mathrm{ABA}$ & $.892^{* *}$ & 1 & & & \\
\hline $\mathrm{GA}_{3}$ & -.167 & -.301 & 1 & & \\
\hline $\mathrm{ZR}$ & -.381 & -.300 & .045 & 1 & \\
\hline $\begin{array}{c}\text { Germination } \\
\text { rate }\end{array}$ & $-.977^{* *}$ & $-.834^{* *}$ & .192 & .429 & 1 \\
\hline
\end{tabular}

Note: $* *$ significant correlation at 0.01 level (bilateral),

*significant correlation at 0.05 level (bilateral)

germinated at $15 / 25^{\circ} \mathrm{C}$. In contrast, those removed from $\mathrm{CK}$ at $20 \mathrm{~d}, 40 \mathrm{~d}$, and $60 \mathrm{~d}$ showed germination rates of $34.67 \%, 33.33 \%$, and $33.67 \%$, respectively. The highest germination rate was after the low-temperature treatment for $60 \mathrm{~d}$. The germination rates of seeds subjected to the low-temperature treatment were markedly higher than those of seeds in the CK.

The seed germination rate was significantly affected by the duration of the low-temperature treatment $(p<0.01)$. In $\mathrm{CK}$, the seed germination rate was approximately $35 \%$ at all time points and was not significantly affected by the duration $(p>0.05)$.

\section{Correlations between Endogenous Hormone Contents and Seed Germination Rate}

Table 2 shows the correlation analysis between the endogenous hormone contents and the germination rate of I. polycarpa seeds at $15 / 25^{\circ} \mathrm{C}$ after the chilling treatment at $5^{\circ} \mathrm{C}$. There was an extremely significant negative correlation between germination rate and IAA and ABA contents. The germination rate was positively correlated with the following hormone ratios: $\mathrm{GA}_{3} / \mathrm{ABA}$, $\left(\mathrm{GA}_{3}+\mathrm{ZR}\right) / \mathrm{ABA}$, and (IAA $\left.+\mathrm{GA}_{3}+\mathrm{ZR}\right) / \mathrm{ABA}$ (Table 3). The germination rate was also positively correlated $\mathrm{GA}_{3} /$ $\mathrm{ABA}+\mathrm{IAA})$ and $\left(\mathrm{GA}_{3}+\mathrm{ZR}\right) /(\mathrm{ABA}+\mathrm{IAA})($ Table 4$)$.

The amounts and ratios of phytohormones changed in seeds of $I$. polycarpa during the $5^{\circ} \mathrm{C}$ treatment. The IAA, $\mathrm{GA}_{3}$, and $\mathrm{ZR}$ contents were higher in the chilling treatment than in the $\mathrm{CK}$, and the $\mathrm{ABA}$ content was lower in the chilling treatment than in the CK. The low temperature treatment released seed dormancy and significantly improved the germination rate, which was significantly negatively correlated with IAA and ABA contents. Germination was also affected by dynamic balance of hormones, and was positively correlated with the following ratios: ( $\left.\mathrm{GA}_{3} / \mathrm{ABA}\right),\left(\mathrm{GA}_{3}+\mathrm{ZR}\right) / \mathrm{ABA}$, $\left.\left(\mathrm{IAA}+\mathrm{GA}_{3}+\mathrm{ZR}\right) / \mathrm{ABA}, \mathrm{GA}_{3} / \mathrm{ABA}+\mathrm{IAA}\right)$, and $\left(\mathrm{GA}_{3}+\mathrm{ZR}\right) /$ $(\mathrm{ABA}+\mathrm{IAA})$.

\section{Effect of IAA on Dormancy Release of Seeds}

Seed germination can be promoted by IAA. A previous study showed that an increase in IAA content led to an increase in seed germination rate [11]. However, other studies have shown that an elevated IAA content can contribute to seed dormancy [12]. Whether IAA promotes or inhibits seed dormancy depends on its concentration and type [13]. Sprouting in the ear of wheat was effectively inhibited by applying IAA solution to Triticum aestivum L. at the mature stage [14]. In a seed germination experiment on Medicago truncatula, germination was promoted by a low IAA concentration and inhibited by a high IAA concentration, and the sensitivity to IAA varied among different plants [15]. Under high salt conditions, exogenous IAA regulated germination of Arabidopsis seeds, and the inhibitory effect became stronger with increasing IAA concentrations [16]. The large amount

Table 3. Correlation analysis between ratios of endogenous hormones and germination rate of Idesia polycarpa at $15 / 25^{\circ} \mathrm{C}$ after a $5^{\circ} \mathrm{C}$ chilling treatment.

\begin{tabular}{|c|c|c|c|c|c|c|c|c|}
\hline & IAA/ABA & $\mathrm{GA}_{3} / \mathrm{ABA}$ & $\mathrm{ZR} / \mathrm{ABA}$ & $\begin{array}{c}\left(\mathrm{IAA}+\mathrm{GA}_{3}\right) / \\
\mathrm{ABA}\end{array}$ & $\begin{array}{c}(\mathrm{IAA}+\mathrm{ZR}) / \\
\mathrm{ABA}\end{array}$ & $\begin{array}{c}\left(\mathrm{GA}_{3}+\mathrm{ZR}\right) / \\
\mathrm{ABA}\end{array}$ & $\begin{array}{c}(\mathrm{IAA}+ \\
\left.\mathrm{GA}_{3}+\mathrm{ZR}\right) / \mathrm{ABA}\end{array}$ & $\begin{array}{c}\text { Germination } \\
\text { rate }\end{array}$ \\
\hline $\mathrm{IAA} / \mathrm{ABA}$ & 1 & & & & & & & \\
\hline $\mathrm{GA}_{3} / \mathrm{ABA}$ & .211 & 1 & & & & & & \\
\hline $\mathrm{ZR} / \mathrm{ABA}$ & -.197 & .371 & 1 & & & & & \\
\hline $\begin{array}{c}(\mathrm{IAA}+\mathrm{GA} \\
\mathrm{ABA}\end{array}$ & .565 & $.926^{* *}$ & .237 & 1 & & & & \\
\hline $\begin{array}{c}(\mathrm{IAA}+\mathrm{ZR}) / \\
\mathrm{ABA}\end{array}$ & .060 & .433 & $.967^{* *}$ & .388 & 1 & & & \\
\hline $\begin{array}{c}(\mathrm{GA}+\mathrm{ZR}) / \\
\mathrm{ABA}\end{array}$ & -.060 & $.708^{*}$ & $.919^{* *}$ & .574 & $.920^{* *}$ & 1 & & $.682^{*}$ \\
\hline $\begin{array}{c}\text { Germination } \\
\text { rate }\end{array}$ & -.457 & $.645^{*}$ & .536 & .368 & .427 & $.589^{*}$ & 1 \\
\hline
\end{tabular}

Note: $* *$ significant correlation at 0.01 level (bilateral), *significant correlation at level 0.05 (bilateral) 
Table 4. Correlation analysis between ratios of endogenous hormones and germination rate of Idesia polycarpa at $15 / 25^{\circ} \mathrm{C}$ after a $5^{\circ} \mathrm{C}$ chilling treatment.

\begin{tabular}{|c|c|c|c|c|}
\hline & $\mathrm{GA}_{3} /(\mathrm{ABA}+\mathrm{IAA})$ & $\mathrm{ZR} /(\mathrm{ABA}+\mathrm{IAA})$ & $\left(\mathrm{GA}_{3}+\mathrm{ZR}\right) /(\mathrm{ABA}+\mathrm{IAA})$ & Germination rate \\
\hline $\mathrm{GA}_{3} /(\mathrm{ABA}+\mathrm{IAA})$ & 1 & & & \\
\hline $\mathrm{ZR} /(\mathrm{ABA}+\mathrm{IAA})$ & .396 & 1 & 1 & \\
\hline$\left(\mathrm{GA}_{3}+\mathrm{ZR}\right) /(\mathrm{ABA}+\mathrm{IAA})$ & $.714^{* *}$ & $.926^{* *}$ & $.707^{*}$ & 1 \\
\hline Germination rate & $.706^{*}$ & .545 & & \\
\hline
\end{tabular}

Note: **significant correlation at 0.01 level (bilateral), *significant correlation at level 0.05 (bilateral)

of IAA produced by transgenic Arabidopsis iaa M-OX strongly inhibited the germination of its seeds [17]. These findings in other studies indicate that auxin plays an important role in regulating seed germination, and mainly has an inhibitory effect [18]. After ABA, which induces and maintains seed dormancy, IAA is the next most important hormone in seed dormancy [19]. In this study, the IAA content in I. polycarpa seeds showed an increasedecrease-increase trend during the chilling treatment. The germination rate was negatively correlated with IAA content, indicating that a higher IAA content inhibited the germination of seeds during the dormancy release process in I. polycarpa.

\section{Effect of ZR on Dormancy Release of Seeds}

The ZR content in I. polycarpa seeds was very low, and the change in the ZR content varied markedly depending on temperature. Under low temperature, ZR can promote

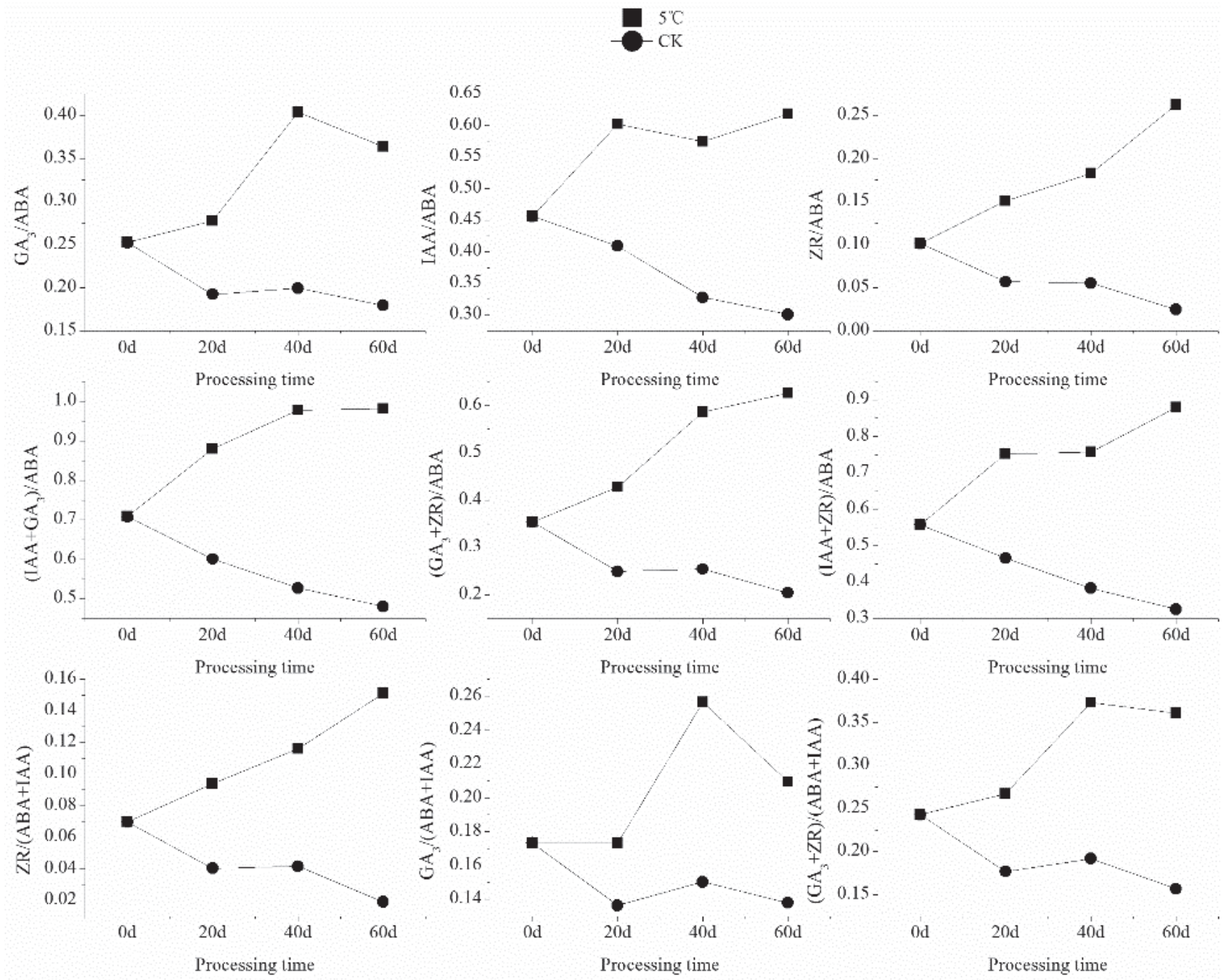

Fig. 6. Changes in endogenous hormone content ratios in Idesia polycarpa seeds from Jiyuan during a chilling treatment at $5^{\circ} \mathrm{C}$. 
dormancy release in seeds of $I$. polycarpa. The results of this study showed that the ZR concentration increased and promoted dormancy release in the chilling treatment, but decreased in the CK. Our results showed that increased ZR resulted in an increase in the germination rate of $I$. polycarpa seeds, consistent with the results of Wang's study on Asarum heterotropoides.

\section{Effect of ABA on Dormancy Release of Seeds}

Seed dormancy and node germination were shown to be controlled by ABA [20]. It has been reported that whether seeds remain dormant or germinate depends on their sensitivity to $\mathrm{ABA}$, rather than their $\mathrm{ABA}$ content [21]. Changes in ABA signals were able to release seed dormancy to some extent [22]. Thus, the content and function of ABA, as well as tissue sensitivity to ABA, affect seed dormancy and germination [23]. The ABA content was significantly and negatively correlated with the germination rate of I. polycarpa seeds, indicating that a decrease in ABA content helped to release seed dormancy and promote germination [24].

\section{Effect of Dynamic Balance of Phytohormones on Dormancy Release of Seeds}

Early genetic studies showed that $\mathrm{ABA}$ and $\mathrm{GA}_{3}$ inhibit each other's synthesis [25]. These two hormones play a decisive role in the process of seed dormancy and germination [26-27]. In another study, whether seeds remained dormant or germinated depended on the relative contents of $\mathrm{ABA}$ and $\mathrm{GA}_{3}$ [7]. In this study, the $\mathrm{GA}_{3}$ content showed a decrease-increase-decrease trend during the chilling treatment, and the germination rate was positively correlated with the $\mathrm{GA}_{3} / \mathrm{ABA}$ ratio. This result indicated that the seed germination of I. polycarpa was affected by the co-operative actions of $\mathrm{GA}_{3}$ and ABA.

Auxin can inhibit germination, similar to ABA. During seed germination, ABA was shown to inhibit hypocotyl elongation via enhancement of the auxin signal [28]. Auxin interacts with $\mathrm{ABA}$ in the regulation of seed germination [29]. Auxin was shown to promote bud dormancy of Marchantia polymorpha L. [30]. However, under drought conditions, mutual antagonism between $\mathrm{ABA}$ and auxin led to the inhibition of lateral root development as a droughtresistance response [31]. This result demonstrated that the relationship between auxin and ABA is not always fixed, and can change during different physiological processes.

After the low-temperature treatment, the seed germination rate of $I$. polycarpa was positively correlated with the following ratios: $\left(\mathrm{GA}_{3}+\mathrm{ZR}\right) / \mathrm{ABA}$, $\left(\mathrm{IAA}+\mathrm{GA}_{3}+\mathrm{ZR}\right) / \mathrm{ABA}, \mathrm{GA}_{3} /(\mathrm{ABA}+\mathrm{IAA})$, and $\left(\mathrm{GA}_{3}+\mathrm{ZR}\right) /$ $(\mathrm{ABA}+\mathrm{IAA})$. This result indicated that the germination rate of I. polycarpa seeds was affected by the synergistic interactions among endogenous hormones.

\section{Acknowledgements}

The authors wish to express their sincere thanks to the personnel of Henan Agricultural University for their kind assistance in the experiments. This research was supported by the Henan Provincial Department of Science and Technology Research Project (182102110070).

\section{References}

1. WANG H.Y. Studies on the vegetative propagation of Idesia polycarpa. Zhengzhou, Henan Agricultural University, 2014.

2. LI S.X., LAN S.R., WU S.S., XU J.Y., ZHAI J.W., PENG D.H. Effects of soaking time and plant growth regulators on germination of Idesia polycarpa Maxim seeds. Seed, 34(4), 8, 2015.

3. FAN G.Q., CAO X.B., NIU S.Y., DENG M.J., ZHAO Z.L., DONG Y.P. Transcriptome, microRNA, and degradome analyses of the gene expression of Paulownia with phytoplamsa. BMC Genomics, 16, 896, 2015.

4. RU G.X., LIU X.N., ZHU X.H., ZHANG L.C., WANG Y.R., ZHOU S.Q.Physiological characteristic analysis of etiolation mutant in paulownia. Journal of Nanjing Forestry University (Natural Science Edition), 41, 1, 2017.

5. TANG X.S., YE Y., AN X.L., TANG L. Effect of Different Storage Methods on Seeds Germination of Idesia polycarpa. Seed, 12, 16, 2013.

6. WANG Y.M., WANG H.Y., DAI L., LI F., LIU Z. Effect of Different Low Temperature Treatments on Breaking Idesia polycarpa Seed Dormancy among 12 Provenances. Journal of Shandong Agricultural University, 46(1), 51, 2015.

7. YU M., XU H., ZHANG H., ZU Y. Regulation of plant hormones on seed dormancy and germination. Plant Physiology Communications, 52 (5), 599, 2016.

8. CHEN Q., GUO Y.H., JIANG Y. Mechanism of fluridoneinduced seed germination of cistanche tubulosa. Pakistan Journal Of Botany 48 (3), 971, 2016.

9. PAWLOWSKI T.A., STASZAK A.M. Analysis of the embryo proteome of sycamore (Acer pseudoplatanus L.) seeds reveals a distinct class of proteins regulating dormancy release. Journal of Plant Hysiology 195, 9, 2016.

10. NIU Y.J., YUAN J.F., CHEN H.X., DONG Q.Q., FAN Y., WANG X.F., LIU Z.H. Germination characteristic and endogenous ABA, IAA content change with HPLC in the seed of Hedysarum laeve maxim during stratifying, shelling. Chinese Agricultural Science Bulletin, 31 (4), 34, 2015

11. WANG Y.M., LIU Z., NIU X.F. Dynamic changes of endogenous hormones in terminal buds from different crown position of one-year-old paulownia. Scientia Silvae Sinicae, 48 (7), 61, 2012.

12. MARTIN S., EKATERINA Y., GERORGI R., KATYA L., YULIANA M., EMAILIA L.A. Effects of salinity on the photosynthetic apparatus of two Paulownia lines. Plant Physiology and Biochemistry, 101, 54, 2016.

13. WANG G.X., GUAN X.,LIU Z., FAN X. Growth and photosynthetic characteristics of buried root seedlings of different paulownia varieties. Journal of Henan Agricultural Sciences, 46 (1), 116,2017.

14. RAMAIH S., GUEDIRA M, PAULSEN G.M. Relationship of indoleacetic acid and tryptophan to dormancy and 
preharvest sprouting of wheat. Funct Plant Biol 30 (9), 939, 2003.

15. ZHENG X.H., ZHENG Z.L. DING H., XIAO S.H., QIN Z.H. ISSR Analysis of Relationship of 12 Accessions of Paulownia fortune. Chinese Journal of Tropical Agriculture, 37 (2), 35, 2017.

16. WANG Y.M., ZHANG L.C., MA X.T., LIU Z.,LIU Z., REN X.M., GENG X.D., SONG L.H. Effect of artificial regulation on terminal bud growth of paulownia spp. Scientia Silvae Sinicae, 52 (8), 53, 2016.

17. JIA H.W., GUO F., WU Y.M., YAO B. The variance analysis of photosynthetic characteristic parameters of different Paulownia Clones. Journal of Henan Agricultural University, 50( 2), 176, 2016.

18. LI Z.H., ZHANG J., LIU Y.L., ZHAO J.H., FU J.J., REN X.L., WANG G.Y., WANG J.H. Exogenous auxin regulates multi-metabolic network and embryo development, controlling seed secondary dormancy and germination in Nicotiana tabacum L. BMC Plant Biol, 16 (1), 41, 2016.

19. LIU X., ZHANG H., ZHAO Y., FENG Z.Y., LI Q. Auxin controls seed dormancy through stimulation of abscisic acid signaling by inducing ARF-mediated ABI3 activation in Arabidopsis, Proc Nati Acad Sci USA, 110 (38), 15485, 2013.

20. ALBERTOS P., ROMERO M.C., TATEMATSU K., MATEOS I. S-nitrosylation triggers ABI5 degradation to promote seed germination and seedling growth. Nature Communications, 6, 8669, 2016.

21. DAI L, CAI Q.F., WANG Y.M. Establishment of ISSR-PCR reaction system of Idesia polycarpa and the screening of primers. Journal of Henan Agricultural University, 47 (5), 548, 2013.

22. FEURTADO J.A., YANG J., AMBROSE S.J., CULTER A.J., ABRAMS S.R., KERMODE A.R. Disrupting abscisic acid homeostasis in western white pine (Pinus monticola Dougl. Ex D. Don) seeds induces dormancy termination and changes in abscisic acid catabolites. Journal of Plant Growth Regulation, 26, 46, 2007.
23. YAN D.F., GAO Y., LIU Z. Screening and evaluation of woody biofuel plants in Henan Province. Journal of Forestry Engineering, 27 (6), 2013.

24. WANG Y.M., MA X.T., LIU Z., WU D.H.,WANG L., WANG J.H. Analysis on grafted less-fruit Platanus acerifolia seedlings based on ISSR marker. Journal of Henan Agricultural University, 50 (5), 629, 2016.

25. NAMBARA E., OKAMOTO M., TATEMATSU K., YANO R., SEO M., KAMIYA Y. Abscisic acid and the control of seed dormancy and germination. Seed Science Research, 20, 55, 2010.

26. SHU K., LIU X.D., XIE Q., HE Z.H. Two faces of one seed: hormonal regulation of dormancy and germination. Mol Plant, 9 (1), 34, 2016.

27. DEKKERS B.J., HE H., HANSON J., WILLEMS A.J., JAMAR C.L., CUEFF G. The Arabidopsis DELAY OF GERMINATION 1 gene affects ABSCISIC ACID INSENSITIVE5 (ABI5) expression and genetically interacts with ABI3 during Arabidopsis seed development. The Plant Journal, 85 (4), 451, 2016.

28. KARPPINEN K., HIRVELA E., NEVALA T., SIPARI N. Changes in the abscisic acid levels and related gene expression during fruit development and ripening in bilberry (Vaccinium myrtillu.s L.). Phytochemistry, 95, 127, 2013.

29. SHUAI H.W., MENG Y.J., LUO X.F., CHEN F., QI Y., YANG W.Y., SHU K. The roles of auxin in seed dormancy and germination. Hereditas, 38(4), 314, 2016.

30. EKLUND D.M., ISHIZAKI K., FLORES E., KLKUCHI S. TAKEBAYASHI Y. Auxin produced by the indole-3pyruvic acid pathway regulates development and gemmae dormancy in the liverwort Marchantia polymorpha. Plant Cell, 27 (6), 1650, 2015.

31. WANG G.X., GENG X.D., ZHANG N., LIU Z., GUAN X., LIU R.X., TIAN Y.F., LUO H.Y. Morphology and microstructure changes of terminal buds of paulownia in autumn and winter. Journal of Northwest Forestry University, 32 (1), 165, 2017. 
